\title{
Effects of soluble immunostimulants on mucosal immune responses in rainbow trout immersion-vaccinated against Yersinia ruckeri
}

Skov, Jakob; Chettri, Jiwan Kumar; Jaafar, Rzgar M.; Kania, Per W.; Dalsgaard, Inger; Buchmann, Kurt

Published in:

Aquaculture

Link to article, DOI:

10.1016/j.aquaculture.2018.04.011

Publication date:

2018

Document Version

Peer reviewed version

Link back to DTU Orbit

Citation (APA):

Skov, J., Chettri, J. K., Jaafar, R. M., Kania, P. W., Dalsgaard, I., \& Buchmann, K. (2018). Effects of soluble immunostimulants on mucosal immune responses in rainbow trout immersion-vaccinated against Yersinia ruckeri. Aquaculture, 492, 237-246. https://doi.org/10.1016/j.aquaculture.2018.04.011

\section{General rights}

Copyright and moral rights for the publications made accessible in the public portal are retained by the authors and/or other copyright owners and it is a condition of accessing publications that users recognise and abide by the legal requirements associated with these rights.

- Users may download and print one copy of any publication from the public portal for the purpose of private study or research.

- You may not further distribute the material or use it for any profit-making activity or commercial gain

- You may freely distribute the URL identifying the publication in the public portal 


\section{Accepted Manuscript}

Effects of soluble immunostimulants on mucosal immune responses in rainbow trout immersion-vaccinated against Yersinia ruckeri

Jakob Skov, Jiwan K. Chettri, Rzgar M. Jaafar, Per W. Kania, Inger Dalsgaard, Kurt Buchmann

PII: $\quad$ S0044-8486(17)32273-1

DOI: doi:10.1016/j.aquaculture.2018.04.011

Reference: AQUA 633175

To appear in: aquaculture

Received date: 15 November 2017

Revised date: 7 March 2018

Accepted date: 8 April 2018

Please cite this article as: Jakob Skov, Jiwan K. Chettri, Rzgar M. Jaafar, Per W. Kania, Inger Dalsgaard, Kurt Buchmann, Effects of soluble immunostimulants on mucosal immune responses in rainbow trout immersion-vaccinated against Yersinia ruckeri. The address for the corresponding author was captured as affiliation for all authors. Please check if appropriate. Aqua(2018), doi:10.1016/j.aquaculture.2018.04.011

This is a PDF file of an unedited manuscript that has been accepted for publication. As a service to our customers we are providing this early version of the manuscript. The manuscript will undergo copyediting, typesetting, and review of the resulting proof before it is published in its final form. Please note that during the production process errors may be discovered which could affect the content, and all legal disclaimers that apply to the journal pertain. 
Effects of soluble immunostimulants on mucosal immune responses in rainbow trout immersion-vaccinated against Yersinia ruckeri

Jakob Skov $^{\text {a }}$, Jiwan K. Chettri ${ }^{\text {a }}$, Rzgar M. Jaafar ${ }^{\mathrm{a}}$, Per W. Kania ${ }^{\mathrm{a}}$, Inger Dalsgaard ${ }^{\mathrm{b}}$, Kurt Buchmann $^{\mathrm{a}, *}$

${ }^{a}$ Department of Veterinary and Animal Science, Faculty of Health and Medical Sciences, University of Copenhagen, Frederiksberg C, Denmark

${ }^{b}$ National Veterinary Institute, Technical University of Denmark, Kgs. Lyngby, Denmark 


\section{ABSTRACT}

Immersion vaccination of rainbow trout against Yersinia ruckeri infection is an established method to prevent enteric red mouth disease (ERM) but the effect is inferior to injection vaccination and the duration of protection is limited to less than six months. Adjuvants in vaccines may in general elevate the immune response and the present work elucidates how ERM immersion vaccination of trout in combination with exposure to soluble adjuvants, Montanide ${ }^{\mathrm{TM}}$ IMS 1312 VG PR and $\beta$ glucan, affects immune reactions. The former adjuvant, when used alone, induced a slightly increased protection (not statistically significant) whereas $\beta$-glucan did not increase protection. Adjuvant-treated and non-exposed groups showed elevated plasma lysozyme activity after challenge with $Y$. ruckeri. Specific antibody production was not positively affected by combining adjuvant and vaccine. Overall expression of immune genes tested was generally manifold higher in gills compared to skin. Only genes encoding SAA and IL-17C1 were expressed at a higher level in skin. Dynamic differences between the gill and skin compartments were also recorded for genes encoding cytokines (TNF- $\alpha$, IL-1 $\beta$, IL-6, IL-10, IL-12, IL-17A/F2, IL-17C1, IL-17C2, IL-22), immunoglobulins (IgM, $\operatorname{IgD}, \operatorname{IgT})$, cell markers $(\mathrm{CD} 8 \alpha, \mathrm{TCR}-\beta)$ and acute phase reactants (SAA, lysozyme). These genes were upregulated $24 \mathrm{~h}$ post-vaccination in fish gills exposed to both vaccine-adjuvant combinations when compared to fish exposed to vaccine alone. After a few weeks no vaccine induced reaction was seen and after challenge with bacteria mainly unvaccinated fish responded. Adjuvants used in combination with immersion vaccine clearly influences immune reactions and may improve duration and protection but further potency tests should be performed.

Keywords: Yersinia ruckeri; Immersion vaccination; Adjuvant; Montanide ${ }^{\mathrm{TM}}$; $\beta$-Glucan

* Corresponding author. Tel: +45 35332700; fax: +45 35332742

E-mail address: $\underline{\text { kub@sund.ku.dk }}$ 


\section{Introduction}

Vaccination is an economic and sustainable strategy to reach disease control and its usage can replace the need for treatments with antibiotics (Brudeseth et al., 2013; Gudding and van Muiswinkel, 2013; Tafalla et al., 2013). Vaccines for fish can be administered by injection, short time immersion (dip), long time immersion (bath) and by oral application in feed (Johnson and Amend, 1983; Jaafar et al., 2017). Immersion vaccination is a convenient way of immunizing small sized fish, which are not readily injectable. It allows processing of large numbers of fish in a short time, reduces stress levels in fish during and following vaccination and is less labor intensive compared to injection at farm level (Chettri et al., 2013, 2015; Dalmo et al., 2016). Immersion vaccination using a bacterin consisting of formalin-killed Yersinia ruckeri, one of the main bacterial pathogens in farming of salmonids in freshwater (Tobback et al., 2007), has been applied by farmers through decades (Newman and Majnarich, 1982; Johnson et al., 1982; Cossarini-Dunier, 1986). The protection conferred is of relatively short duration but booster vaccination can prolong the effect (Chettri et al. 2013, 2015; Schmidt et al., 2016). The relatively low efficacy of immersion compared to injection of the vaccine may be due to a lower amount of antigen reaching the central immune organs whereby stimulation of immune processes is limited.

It has been suggested that adjuvants significantly improve responses and protection induced by vaccines (Dalmo et al., 2016). Thus, applied by injection (Jaafar et al., 2015; Soltani et al., 2016) and immersion vaccines (Jeney and Anderson, 1993; Soltani et al., 2014), adjuvants may reinforce immune-stimulation and protection and it is therefore relevant to explore the efficacy and underlying, immune-enhancing mechanisms of vaccine-adjuvant combinations. A commercial adjuvant (Montanide ${ }^{\mathrm{TM}}$ IMS 1312 VG PR) administered with an $Y$. ruckeri bacterin was previously shown to improve protection against ERM (Soltani et al., 2014). Other immune-stimulating compounds may find application as adjuvants. Candidates include MacroGard from yeast 
(Saccharomyces cerevisiae), cereal glucan from barley (Hordeum vulgare), or laminarin from brown algae (Laminaria hyperborea). It has been demonstrated that bath exposure of fish to various types of these $\beta$-glucans, applied without the presence of a vaccine, improves wound healing in carp (Przybylska-Diaz et al., 2013), leukocyte numbers and phagocytic ratio (Jeney and Anderson, 1993), and immune gene expression (Zhang et al., 2009) in rainbow trout. Positive effects of yeast wall glucan and cereal glucan, when delivered as adjuvant in vaccines by intraperitoneal injection or bath exposure, have been reported in Atlantic salmon (Rørstad et al., 1993) and rainbow trout (Jeney and Anderson, 1993), respectively. The aim of the present study was to evaluate the immunogenic and disease preventive potential in rainbow trout of two different adjuvants, i.e. the commercially available Montanide ${ }^{\mathrm{TM}}$ IMS 1312 VG PR and a yeast (S. cerevisiae) cell wall glucan, when co-administered with the immersion vaccine AquaVac ${ }^{\circledR}$ Relera. Protection following dip vaccination and subsequent bath challenge with $Y$. ruckeri was recorded and associated immune parameters described. These factors comprise gene regulation in skin and gill tissue, plasma lysozyme activity and antibody production.

\section{Materials and methods}

\subsection{Fish and rearing conditions}

Female rainbow trout (Oncorhynchus mykiss) $(n=560$, Fousing strain, Jutland), hatched from disinfected eggs and reared under pathogen-free conditions (Xueqin et al., 2012) at the Bornholm Salmon Hatchery (Nexø, Denmark), were brought to the University of Copenhagen when reaching a mean weight of $7 \mathrm{~g}$ (600 degree days post-hatch). Fish were divided into fourteen $120 \mathrm{~L}$ aquaria (40 fish per aquarium) and acclimated to experimental rearing conditions, i.e. aerated municipal

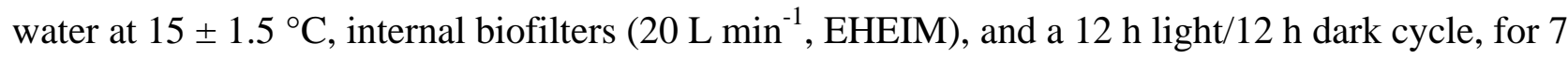
days prior to initiation of the experiment. Feed (INICIO 917, BioMar A/S) was provided at a rate of 
$1.5 \%$ biomass day $^{-1}$ during the acclimation and experimental period. The experiment was approved by the experimental animal inspectorate under the Ministry of Environment and Food and performed under license 2015-15-0201-00508. All animal procedures applied during the present study complied with the EU Directive 2010/63/EU for animal experiments.

\subsection{Experimental design}

The adjuvant Montanide ${ }^{\mathrm{TM}}$ (MA) or yeast wall glucan (YWG) were combined with vaccine administration as follows: A total of seven groups were studied in duplicate, i.e. 1) MA (alone), 2) YWG (alone), 3) vaccine (alone), 4) vaccine + MA, 5) vaccine + YWG, 6) unvaccinated fish (control fish for challenge) and 7) unvaccinated fish kept unchallenged throughout the experiment. Groups 1-6 were challenged by immersion into a solution of Y. ruckeri as described below (see 2.5). Ten fish were sampled from each group (i.e. 5 fish per replicate) $1 \mathrm{~d}$ post-vaccination (p.v.), $1 \mathrm{~d}$ pre-challenge, $3 \mathrm{~d}$ post-challenge (p.c.), and $24 \mathrm{~d}$ p.c. Blood was sampled at each sampling timepoint for measurement of plasma lysozyme activity and specific IgM antibody levels, and skin and gill tissues were sampled to study immune gene regulation.

\subsection{Vaccine and adjuvants}

AquaVac $^{\circledR}$ Relera Vet. (MSD Animal Health), a commercial ERM immersion vaccine based on inactivated cells of $Y$. ruckeri biotype 1 (Hagerman) and $Y$. ruckeri biotype 2 (EX5), was applied for specific immunization of the fish against $Y$. ruckeri (see 2.4). Montanide ${ }^{\mathrm{TM}}$ IMS 1312 VG PR (Seppic) (MA), an adjuvant product for immersion vaccination, was applied with and without vaccine and a yeast wall $\beta$-glucan (YWG) from baker's yeast (Saccharomyces cerevisiae) (purity 98\%, solubility $9.8-10.0 \mathrm{mg} \mathrm{mL}^{-1}$ in water) (Cat. no. G5011, Sigma-Aldrich) was studied as an alternative adjuvant candidate. Preparation of vaccine and/or adjuvant solutions was conducted according to the following protocol: The day before immersion of fish, 5 premixes $(1 \mathrm{~L}$ each) were prepared, i.e. $500 \mathrm{~mL} \mathrm{MA}+500 \mathrm{~mL} \mathrm{H}_{2} \mathrm{O}$ (tap water in all cases); $75 \mathrm{mg} \mathrm{YWG}+1000 \mathrm{~mL} \mathrm{H}_{2} \mathrm{O}$, 
$500 \mathrm{~mL}$ vaccine $+500 \mathrm{~mL} \mathrm{H} \mathrm{H}_{2} \mathrm{O} ; 500 \mathrm{~mL}$ vaccine $+500 \mathrm{~mL}$ MA; $500 \mathrm{~mL}$ vaccine $+75 \mathrm{mg}$ YWG in $500 \mathrm{~mL} \mathrm{H} \mathrm{H}_{2} \mathrm{O}$. Premixes were stirred in $2 \mathrm{~L}$ glass beakers $(\varnothing 120 \mathrm{~mm})$ at a magnetic stirrer $\left(L_{\text {magnet }}=\right.$ $40 \mathrm{~mm}, 300 \mathrm{rpm}$ ) at room temperature for $6 \mathrm{~h}$, stored without stirring at $4{ }^{\circ} \mathrm{C}$ overnight, stirred again as previously at room temperature for $4 \mathrm{~h}$ and adjusted to final volumes of $5 \mathrm{~L}$ by adding $4 \mathrm{~L}$ $\mathrm{H}_{2} \mathrm{O}$ immediately before immersion of fish for vaccination and exposure to adjuvants. Thus, final dilutions of MA and vaccine were 1:10 each, and the final concentration of YWG was $15 \mathrm{mg} \mathrm{L}^{-1}$.

\subsection{Vaccination and exposure to adjuvants}

Forty fish in duplicate were exposed to either 1) a $30 \mathrm{~s}$ dip in $5 \mathrm{~L}$ of a 1:10 dilution of the vaccine AquaVac $^{\circledR}$ Relera Vet. (MSD Animal Health), 2) a $30 \mathrm{~s}$ dip in vaccine + MA, 3) a $30 \mathrm{~s}$ dip in vaccine + YWG, 4) a $30 \mathrm{~s}$ dip in MA (alone), 5) a $30 \mathrm{~s}$ dip in YWG (alone) or 6) a $30 \mathrm{~s}$ dip in pure tap water (unvaccinated controls). In addition, $2 \times 40$ fish were kept as 6 ) in pure tap water but were not subsequently exposed to live bacteria whereby 560 fish in total were used for the study. The day of vaccination and exposure to adjuvants defined day 0 of the experiment.

\subsection{Challenge}

Thirty and 42 days (450 and 630 degree days, respectively) following vaccination, fish were bathchallenged: A primary challenge was performed for $6 \mathrm{~h}$ in a concentration of $1.4 \times 10^{7} \mathrm{CFU} \mathrm{mL}^{-1}$ of Y. ruckeri $\mathrm{O} 1$ biotype $2(100415-1 / 4)$ and a secondary challenge for $8 \mathrm{~h}$ in $1.1 \times 10^{7} \mathrm{CFU} \mathrm{mL} \mathrm{m}^{-1}$ of the same strain (Dalsgaard and Madsen, 2000; Wheeler et al., 2009). Fish were subsequently monitored at $2 \mathrm{~h}$ intervals for 24 days and moribund individuals were euthanized by immersion in an overdose (200 $\left.\mathrm{mg} \mathrm{L}^{-1}\right)$ of ethyl 3-aminobenzoate methanesulfonate (MS-222) (Cat. no. A5040, Sigma-Aldrich) and recorded as mortalities. The cause of morbidity following challenge was confirmed by culturing swab samples of head kidney from euthanized fish on 5\% blood agar (Cat. no. 677 , SSI Diagnostica) at $20{ }^{\circ} \mathrm{C}$ for $48-72$ hours.

\subsection{Sampling of blood, skin and gills}


Following euthanization in an overdose of MS-222 blood for antibody and lysozyme activity assays was drawn from vena caudalis using Na-heparinized $75 \mu \mathrm{L}$ micro-hematocrit tubes (Vitrex Medical A/S). Following centrifugation at $3000 \mathrm{~g}$ for $10 \mathrm{~min}$ at $4{ }^{\circ} \mathrm{C}$ (Universal $320 \mathrm{R}$, Hettich), plasma was isolated and stored at $-80{ }^{\circ} \mathrm{C}$. Skin and gill tissues were sampled from the left side of the fish for gene expression analysis. Thus, from the left side, skin (excluding underlying muscle tissue) from the upper anterior quadrant of the body and gill arches $\left(1^{\text {st }}, 2^{\text {nd }}\right.$ and $\left.3^{\text {rd }}\right)$ were sampled, immersed in RNAlater $^{\circledR}$ (Cat. no. R0901, Sigma-Aldrich), pre-stored at $4{ }^{\circ} \mathrm{C}$ for $24 \mathrm{~h}$ and then transferred to -20 ${ }^{\circ} \mathrm{C}$ until processing.

\subsection{Lysozyme assay}

Plasma lysozyme activity was assessed by the turbidimetric assay (Ellis, 1990; Skov et al., 2012). In brief, a volume of $190 \mu \mathrm{L}$ substrate suspension of Micrococcus lysodeikticus (Cat. no. M3770, Sigma-Aldrich) at a concentration of $0.2 \mathrm{mg} \mathrm{mL}^{-1}$ in sodium phosphate buffer (0.06 M, pH 6.2) was added to $10 \mu \mathrm{L}$ plasma in triplicate on microplates (Cat. no. 655180 , CELLSTAR ${ }^{\circledR}$, Greiner BioOne) and plate-shaken at $100 \mathrm{rpm}$ for $30 \mathrm{~s}$. Optical density (OD) was measured at $450 \mathrm{~nm}$ after 1 min and 5 min at $23{ }^{\circ} \mathrm{C}$ (Epoch Spectrophotometer, BioTek Instruments, Inc.).

\subsection{Enzyme-linked immunosorbent assay (ELISA)}

Yersinia ruckeri-specific IgM antibody levels in plasma were measured by ELISA. Microplates (F96 Maxisorp, Nunc) were coated with $100 \mu \mathrm{L}_{\text {well }}{ }^{-1}$ of formalin-killed and sonically disrupted $Y$. ruckeri $\mathrm{O} 1$ biotype $2(100415-1 / 4)\left(5 \mu \mathrm{g}\right.$ protein $\left.\mathrm{mL}^{-1}\right)$ in bicarbonate coating buffer (Cat. no. C3041, Sigma-Aldrich) by incubation overnight at $4{ }^{\circ} \mathrm{C}$. Non-specific binding sites were blocked for $1 \mathrm{~h}$ by $2 \%$ bovine serum albumin (BSA) in phosphate-buffered saline (PBS, pH 7.4, room temperature, $100 \mu \mathrm{L}_{\text {well }}{ }^{-1}$ ). Plasma samples were diluted 1:50 and 100 $\mu \mathrm{L}$ of diluted sample was added to duplicate wells and incubated overnight at $4{ }^{\circ} \mathrm{C}$. Mouse anti-salmonid Ig (Cat. no. MCA2182, AbD Serotec ${ }^{\circledR}$; diluted 1:500) and HRP (horseradish peroxidase)-conjugated rabbit anti- 
mouse IgG (Cat. no. STAR13B, AbD Serotec ${ }^{\circledR}$; diluted 1:500) were used as primary and secondary antibodies, respectively. Each of the steps described above were followed by 3 washes in wash buffer (PBS with 0.1\% Tween 20, pH 7.4). TMB Core+ substrate (Cat. no. BUF062C, AbD Serotec $\left.^{\circledR}\right)\left(100 \mu \mathrm{L}_{\text {well }}{ }^{-1}\right)$ was added for colour development, the reaction was stopped after 15 min by adding $1 \mathrm{M} \mathrm{HCl}\left(100 \mu \mathrm{L}_{\text {well }}{ }^{-1}\right)$ whereafter OD was measured at $450 \mathrm{~nm}$ (Epoch Spectrophotometer, BioTek Instruments, Inc.).

\subsection{RNA isolation, $c D N A$ synthesis and quantitative reverse transcription $P C R(q P C R)$}

Skin and gill samples were homogenized and lysed using a lysis solution (Cat. no. L8285) of the GenElute $^{\mathrm{TM}}$ kit (Cat. no. RTN350-1KT, Sigma-Aldrich) at $20 \mathrm{~Hz}$ for 4-6 min (TissueLyser II, QIAGEN) using $2 \mathrm{~mL}$ tubes (Cat. no. E1420-2341, ALMECO) and $5 \mathrm{~mm}$ beads (Cat. no. 69989, QIAGEN). Skin lysates were treated with proteinase K (Cat. no. 1019499, QIAGEN) according to the user guide of the GenElute ${ }^{\mathrm{TM}}$ kit (Cat. no. RTN350-1KT, Sigma-Aldrich), which was subsequently used for RNA isolation. Genomic DNA was removed by DNase I (Cat. no. EN0521, Thermo Scientific), and purity and concentration of RNA were measured at 260/280 nm (NanoDrop 2000 Spectrophotometer, Thermo Scientific). DNase efficacy and RNA integrity were confirmed by electrophoresis through $1.5 \%$ (w/v) agarose gels containing ethidium bromide $\left(0.04 \mu \mathrm{L} \mathrm{mL}^{-1}\right)$. Isolated RNA was stored at $-80^{\circ} \mathrm{C}$ until reversely transcribed to cDNA using oligo $\mathrm{d}(\mathrm{T}) 16$ primers and reagents from TaqMan $^{\circledR}$ Reverse Transcription Reagents (Cat. no. N8080234, Applied Biosystems) in a $20 \mu \mathrm{L}$ reaction volume containing $1000 \mathrm{ng}$ RNA as template under the following conditions: annealing at $25{ }^{\circ} \mathrm{C}$ for $10 \mathrm{~min}$, elongation at $37{ }^{\circ} \mathrm{C}$ for $60 \mathrm{~min}$, and inactivation at $95{ }^{\circ} \mathrm{C}$ for $5 \mathrm{~min}\left(\mathrm{~T} 100^{\mathrm{TM}}\right.$ Thermal Cycler, BIORAD). The cDNA product was diluted $10 \times$ by addition of $180 \mu \mathrm{L}$ DNase-/RNase-free $\mathrm{H}_{2} \mathrm{O}$ (Cat. no. 10977035, Gibco ${ }^{\circledR}$, Life Technologies ${ }^{\mathrm{TM}}$ ) and stored at $20{ }^{\circ}$ C. qPCR assays were performed in an AriaMx Real-Time PCR System (Agilent Technologies). Reaction volumes included 6.25 $\mu \mathrm{L}$ Brilliant II QPCR Master Mix (Cat. no. 600804, Agilent 
Technologies), a $0.5 \mu \mathrm{L}$ mix of forward primer, reverse primer, and TaqMan ${ }^{\circledR}$ probe, $3.25 \mu \mathrm{L}$ DNase-/RNase-free $\mathrm{H}_{2} \mathrm{O}$, and $2.5 \mu \mathrm{L}$ template cDNA adding up to a total of $12.5 \mu \mathrm{L}$ and resulting in the following concentrations: $\mathrm{MgCl}_{2}(5.5 \mathrm{mM})$, forward and reverse primer $(0.4 \mu \mathrm{M}$ each), and TaqMan $^{\circledR}$ probe $(0.2 \mu \mathrm{M})$. Cycling conditions comprised an initial denaturation step (95 ${ }^{\circ} \mathrm{C}, 15$ min) followed 40 cycles of denaturation $\left(95^{\circ} \mathrm{C}, 15 \mathrm{~s}\right)$, and combined annealing and elongation (60 ${ }^{\circ} \mathrm{C}, 45 \mathrm{~s}$ ). Controls included in each assay comprised reaction solutions without transcriptase (no reverse transcriptase) and solutions without template (no template). Target genes analyzed, and primers and probes applied in qPCR assays, are listed in Table 1.

\subsection{Data analysis and statistics}

Prior to analysis duplicate groups were combined as they did not differ significantly (Student's ttest, $P>0.05$ ). Relative percent survival (RPS) was calculated by the end of the experiment ( $24 \mathrm{~d}$ p.c. $)$ as $1-(\%$ vaccinate or adjuvant mortality $/ \%$ control mortality $) \times 100$ (Amend, 1981). Survival curves were produced and analyzed by the Kaplan-Meier method applying the log rank test. Oneway ANOVA with Tukey's multiple comparison test was applied to test for inter-group differences regarding plasma lysozyme activity and antibody levels. Gene expression data for each gene was normalized against elongation factor- $1 \alpha(\mathrm{EF}-1 \alpha)$ and interpreted according to the ${ }^{-\Delta \Delta} \mathrm{Ct}$ method (Livak and Schmittgen, 2001) without efficiencies correction, as the efficiencies of all assays were within $100 \% \pm 5 \% .{ }^{-\Delta \Delta} \mathrm{Ct}\left({ }^{-\Delta \Delta} \mathrm{Cq}\right)$ values were used to test for significant differences between the different treatment groups vs. the uninfected control, and vaccine-adjuvant combinations vs. vaccine alone, applying Student's t-test (Schmittgen and Livak, 2008). Differences between groups were considered significant at $P<0.05$, and for gene expression data, an additional criteria of a relative fold change $\geq 2$ was required. GraphPad Prism 7.0 was applied for all statistical analyses.

\section{Results}

\subsection{Survival post-challenge}


Cumulative mortality (CM) in unvaccinated controls, fish exposed to $\beta$-glucan (YWG), and fish exposed to Montanide ${ }^{\mathrm{TM}}$ (MA) reached 42\%, 40\% (RPS 4.8), and 28\% (RPS 33.3), respectively. Mortalities did not differ significantly (YWG vs. unvac. controls, $P=0.9224$; MA vs. unvac. controls, $P=0.1531$; YWG vs. MA, $P=0.2187)$. Fish vaccinated with and without MA as adjuvant showed $100 \%$ survival, whereas fish exposed to the YWG-adjuvanted vaccine showed a CM of $4 \%$ (RPS 90.5) (Vaccine + YWG vs. Vaccine, $P=0.1594)$. All vaccinated fish (adjuvanted and nonadjuvanted) experienced improved survival compared to unvaccinated controls and fish exposed to adjuvant alone $(P<0.0009)$. A non-significant trend for increased survival was noted in fish exposed to MA alone $(P=0.15)$. Non-infected controls showed $100 \%$ survival (Fig. 1).

\subsection{Lysozyme activity in plasma}

No significant differences between groups with regard to plasma lysozyme activity were observed pre-challenge, i.e. $1 \mathrm{~d}$ p.v. and $29 \mathrm{~d}$ p.v ( $1 \mathrm{~d}$ pre-challenge). The plasma lysozyme activity of uninfected controls and vaccinated fish remained at pre-challenge levels at all sampling time-points throughout the study. Three days p.c., fish exposed to MA alone and YWG alone showed significantly increased plasma lysozyme activity as compared to controls and vaccinated fish, i.e. MA alone vs. uninfected and infected controls and all vaccinated fish $(P<0.01)$, and YWG alone vs. infected controls and all vaccinated fish $(P<0.05)$. At day 24 p.c., plasma lysozyme activity of infected controls $(P<0.05)$ and fish exposed to MA alone $(P<0.0001)$ and YWG alone $(P<$ 0.001) was significantly increased compared to uninfected controls. Further, fish exposed to MA alone showed a significantly different lysozyme activity level compared to all three vaccinated groups $(P<0.0001)$, whereas YWG alone was significantly different from two of the vaccinated groups, i.e. Vaccine + MA and Vaccine + YWG $(P<0.01)($ Fig. 2A).

\subsection{Antibodies in plasma against $\mathrm{Y}$. ruckeri}


At $1 \mathrm{~d}$ p.v., 29 d p.v. (1 d pre-challenge), and 3 d p.c., Y. ruckeri antibody levels in plasma of all groups were found to be at the same level as in plasma of unvaccinated, uninfected controls $(P>$ 0.9999). Twenty-four days p.c., the antibody levels of unvaccinated fish and fish exposed to MA alone and YWG alone were significantly different from unvaccinated, uninfected controls and all groups of vaccinated fish $(P<0.0001)$. No significant differences were found among unvaccinated fish and those exposed to MA alone and YWG alone $(P=0.9878)$ as well as among unvaccinated, uninfected controls and all vaccinated groups $(P=0.6829)($ Fig. $2 B)$.

\subsection{Gene expression}

The overall percentage of samples reaching a $\mathrm{Cq}$ value in the qPCR analysis, including all genes examined, was $95 \%$ in gill tissue compared to $84 \%$ in skin tissue. The 19 examined genes showed generally different levels of expression (Fig. 3A, B). When the overall expression of genes was analyzed (all time-points) it became clear that 17 of 19 genes showed a manifold higher expression in gills compared to skin (Fig. 3C). Only genes encoding SAA and IL-17C1 were expressed at a higher level in skin. Significant regulation was found for 18 genes in gills compared to 15 in skin. For genes showing significant regulation, the total number of gene regulations observed among all experimental groups throughout the study was 105 in gill tissue compared to 52 in skin tissue. Generally, the most pronounced gene regulations were observed $1 \mathrm{~d}$ p.v. and $3 \mathrm{~d}$ p.c., whereas no or only slight regulations were found $1 \mathrm{~d}$ pre-challenge (Fig. 4 and 5) (Supplementary Table S1).

\subsubsection{Cytokines}

All genes encoding cytokines (IL-1 $\beta$, IL-6, IL-8, IL-10, IL-12, IL-17A/F2, IL-17C1, IL-17C2, IL22 , and TNF- $\alpha$ ) examined in the present study showed significant regulation as a result of exposure to at least one of the adjuvants, the vaccine alone, or one of the vaccine-adjuvant combinations in at least one of the two compartments (gill and/or skin) investigated. Mainly gills showed elevated gene regulations. Significant regulations were mainly observed in gill tissue and considerable 
variations were observed with regard to expression profiles of genes encoding IL-1 $\beta$, IL-6, IL-8, IL12, IL-17A/F2, IL-17C1, IL-22, TNF- $\alpha$ in gill vs. skin. Further, cytokine genes $I L-10$ and $I L-17 C 2$ were significantly regulated in gills only. The gene encoding the key proinflammatory cytokine Interleukin-1 $\beta$ (IL-1 $\beta$ ), which is a good indicator for immune genes highly regulated, was significantly upregulated in gill tissue at $1 \mathrm{~d}$ p.v. for MA (2.7 fold), Vaccine + MA (4.8 fold), and Vaccine + YWG (2.5 fold), whereas a significant downregulation (-2.6 fold) was observed for the vaccine alone, making the effect of both adjuvants in combination with the vaccine significantly different from that of the vaccine alone. At 3 d p.c., IL-1 $\beta$ was significantly upregulated for MA (11.9 fold) and YWG (6.5 fold), and significantly downregulated for Vaccine + YWG (-3.0 fold). Thus, a significant difference was observed for Vaccine + YWG vs. Vaccine. In skin tissue $(1 \mathrm{~d}$ p.v.), IL-1 $\beta$ was significantly upregulated for MA (4.7 fold) and a significant difference between Vaccine + MA and the vaccine alone was observed. At 3 d p.c., significant upregulation of IL-1 $\beta$ was found for MA (3.8 fold) and YWG (2.7 fold) (Fig. 4F and Fig. 5F). The overall expression profile of IL-1 $\beta$ found and described above was in line with those of the majority of the cytokines, i.e. IL-6, IL-8, IL-10, IL-12, and TNF- $\alpha$, examined in gill tissue in. For expression profiles and exact fold changes of all cytokines investigated see Fig. 4 and 5, and Supplementary Table S1.

\subsubsection{Serum amyloid $A(S A A)$}

The gene encoding Serum amyloid A was significantly upregulated in gill tissue $1 \mathrm{~d}$ p.v. for Vaccine + MA (2.7 fold) and Vaccine + YWG (2.8 fold) both being significantly different from the vaccine alone resulting in a significant downregulation (-4.2 fold), whereas no SAA gene regulation was detected in skin tissue at this time-point. At 3 d p.c., SAA was significantly upregulated in gill tissue of fish exposed to MA (10.7 fold) and YWG (4.9 fold), while Vaccine + YWG resulted in a significant downregulation (-2.6 fold) making the combination of vaccine and YWG significantly different from vaccine, which did not induce regulation. In skin tissue (3 d p.c.), SAA was 
upregulated in fish exposed to MA (5.3 fold) and YWG (3.4 fold), whereas none of the vaccinated fish did regulate SAA (Fig. 4P and Fig. 5N).

\subsubsection{Lysozyme}

Expression in gill tissue of the gene for lysozyme was significantly upregulated $1 \mathrm{~d}$ after exposure to YWG (2.9 fold), Vaccine + MA (3.6 fold), and Vaccine + YWG (4.5 fold), whereas a significant downregulation was observed for vaccine alone (-2.9 fold). In skin tissue (1 d p.v.), significant upregulations were observed for MA (2.4 fold), YWG (3.7 fold), Vaccine + MA (2.2 fold), and Vaccine + YWG (2.2 fold). At 3 d p.c., gill samples showed significantly upregulated lysozyme gene expression for MA (2.3 fold) and YWG (2.2 fold), and a significant downregulation for Vaccine + YWG (-2.3 fold). The effect of the combination of vaccine and YWG (-2.3 fold) was significantly different from that of the vaccine alone, which gave rise to no regulation. Significant regulations in skin at 3 d p.c. were all downregulations, i.e. Unvaccinated + Infected (-2.4 fold), YWG (-3.1 fold), and Vaccine (-2.4 fold). In skin tissue, Vaccine + MA (non-regulated) was significantly different from vaccine alone, which was downregulated (-2.4 fold) (Fig. $4 \mathrm{O}$ and Fig. $5 \mathrm{M})$.

\subsubsection{T cell receptors}

The gene encoding T cell co-receptor CD4 was not regulated in gills at any sampling time-point, whereas a significant 2.3-fold upregulation was observed in skin $1 \mathrm{~d}$ post exposure to Vaccine + MA (Fig. 5A). CD8 $\alpha$ was significantly upregulated in gills of fish $1 \mathrm{~d}$ post exposure to MA (2.9 fold), YWG (5.3 fold), Vaccine + MA (7.6 fold), and Vaccine + YWG (7.8 fold). It was noted that both combinations of vaccine and adjuvants induced reactions significantly different from the vaccine (alone) response which did not involve regulation of the $\operatorname{CD} 8 \alpha$ gene by itself. At $3 \mathrm{~d}$ p.c., CD8 $\alpha$ was significantly downregulated in gills of fish exposed to Vaccine + MA (-3.3 fold) and Vaccine + YWG (-8.1 fold), making Vaccine + YWG significantly different from the vaccine alone 
(Fig. 4A). In skin tissue, CD8 $\alpha$ regulation was limited to a significant 2.1-fold downregulation $1 \mathrm{~d}$ p.e. to MA (Fig. 5B). T cell receptor $\beta$ (TCR- $\beta$ ) was significantly upregulated in gill tissue $1 \mathrm{~d}$ p.e. to Vaccine + MA (4.3 fold) and Vaccine + YWG (4.0 fold), whereas exposure to the vaccine alone resulted a 2.4-fold downregulation at this time-point. At 3 d p.c., Vaccine + MA and Vaccine + YWG resulted in significant TCR- $\beta$ gene downregulations of -2.1 and -3.4 fold, respectively, with the effect of Vaccine + YWG being significantly different from that of the vaccine alone (Fig. 4Q). TCR- $\beta$ was not regulated at all in skin tissue.

\subsubsection{Immunoglobulins}

The gene for membrane-bound $\operatorname{IgD}(\mathrm{mIgD})$ was significantly upregulated in gills of YWG-exposed fish (2.7 fold), Vaccine + MA (4.0 fold) and Vaccine + YWG (5.5 fold), and downregulated for vaccine alone (-3.5 fold) at $1 \mathrm{~d}$ p.v. with both combinations of vaccine and adjuvant being significantly different from the vaccine itself. In skin ( $1 \mathrm{~d}$ p.v.), significant mIgD gene regulation was restricted to fish exposed to YWG only (3.1 fold upregulated). At 3 d p.c., mIgD was significantly downregulated in gills for Vaccine + MA (-2.9 fold) and Vaccine + YWG (-4.9 fold), with a significant difference between Vaccine + YWG and the vaccine alone, and significantly downregulated in skin for infected controls (Unvaccinated + Infected; -2.1 fold) and YWG (-4.1 fold) (Fig. 4B and Fig. 5C). The gene encoding secreted $\operatorname{IgD}(\mathrm{sIgD})$ was poorly expressed in the skin with a limited proportion $(33.4 \%)$ of the total no. of skin tissue samples reaching a Cq value compared to $87.1 \%$ for gill tissue samples. Thus, sIgD gene expression data from skin was not considered for further analysis. In gills ( 1 d p.v.), sIgD was significantly upregulated for MA (4.7 fold), YWG (13.4 fold), Vaccine + MA (9.3 fold), and Vaccine + YWG (4.8 fold) with both combinations of vaccine and adjuvants being significantly different from the vaccine alone, which remained unregulated. At 3 d p.c., sIgD was significantly downregulated for infected controls (Unvaccinated + Infected; -3.2 fold), MA (-3.9 fold), Vaccine + MA (-3.5 fold), and Vaccine + 
YWG (-6.9 fold), whereas no regulation was observed for vaccine alone and YWG alone (Fig. 4C). The IgM gene was significantly downregulated in gill tissue of fish exposed to the vaccine alone (2.3 fold), whereas significant upregulations were observed for both Vaccine + MA (3.1 fold) and Vaccine + YWG with significant difference to the vaccine alone in both cases $(1 \mathrm{~d}$ p.v.). At 3 d p.c., the only significant IgM regulation in gill tissue was observed for YWG (4.5 fold upregulated) (Fig. 4D). IgM was hardly regulated in skin tissue and significant changes in expression were limited to a downregulation for MA (-3.5 fold) at $1 \mathrm{~d}$ p.v., and an upregulation for YWG (2.9 fold) at $3 \mathrm{~d}$ p.c. (Fig. 5D). IgT was significantly upregulated in gills for Vaccine + MA (2.9 fold) and Vaccine + YWG (3.9 fold) at $1 \mathrm{~d}$ p.v., both being significantly different from the vaccine alone, which were found unregulated. Likewise, in skin tissue at $1 \mathrm{~d}$ p.v., IgT was significantly upregulated Vaccine + MA fish (4.2 fold) and Vaccine + YWG (3.0 fold) with no regulation observed for the vaccine alone. In this case only Vaccine + MA showed significant difference from the vaccine without adjuvant. At 3 d p.c., in gill tissue, IgT was significantly downregulated for unvaccinated controls (Unvaccinated + Infected; -2.2 fold), Vaccine + MA (-2.3 fold), and Vaccine + YWG (-4.9 fold) with the latter being significantly different from the vaccine alone, which showed no regulation at this time-point. In skin tissue at 3 d p.c., IgT regulation was found for YWG (3.3 fold upregulated), Vaccine, Vaccine + YWG (-2.4 and -2.1 fold downregulated, respectively). The combination Vaccine + MA was unregulated but significantly different from the fish receiving the vaccine without adjuvant (Fig. 4E and Fig. 5E).

\section{Discussion}

The present study confirmed previous investigations (Newman and Majnarich 1982; Johnson et al., 1982; Cossarini-Dunier, 1986; Chettri et al., 2013) showing that immersion vaccination of rainbow trout using a $Y$. ruckeri bacterin induces a significant protection against ERM when challenged few weeks or months post-vaccination. In the present study the protection was high, resulting in $100 \%$ 
survival, and therefore any synergistic effect of adjuvants could not be disclosed directly from the survival data. However, the associated measurements of immune parameters in treated trout reflected significant effects of the applied adjuvants/immunostimulants. Adjuvants are generally recognized as pivotal elements in vaccinology and studies on effects of adjuvants in injection vaccines for fish have suggested that the Montanide ISA 763 A VG product increases protection of rainbow trout when exposed to live Y. ruckeri bacteria (Jaafar et al., 2015; Dalmo et al., 2016; Soltani et al., 2016). It was therefore noteworthy that fish exposed to the water-soluble adjuvant Montanide ${ }^{\text {TM }}$ IMS 1312 VG PR (without inclusion of vaccine) in the present study showed a trend for increased survival (compared both to untreated controls and $\beta$-glucan-treated fish) following challenge although it was not statistically significant. A protective effect of this adjuvant applied with an ERM vaccine was previously suggested by Soltani et al. (2014). The failure of $\beta$-glucan to enhance protection in itself was noted. This corresponds to a previous study by Selvaraj et al. (2006), who vaccinated carp by immersion with and without $\beta$-glucan and found no effect of $\beta$ glucan on survival following challenge with Aeromonas hydrophila. The analyses of immune parameters in exposed trout showed that neither adjuvant exposure alone nor combinations of vaccine and adjuvant resulted in a significantly elevated lysozyme level in plasma but following exposure to live $Y$. ruckeri these and non-treated control groups experienced a higher lysozyme production. Therefore, the lysozyme measurements primarily reflect that fish increase lysozyme production when they are exposed to live bacteria. However, a non-significant trend for increased lysozyme activity in fish $1 \mathrm{~d}$ after being exposed to adjuvants only was noted suggesting that the applied immunostimulants may influence innate responses as suggested by Skov et al. (2012). With regard to the adaptive effector molecule IgM no effects of the different treatments were seen before challenge. Following challenge using live bacteria, IgM titers in plasma from vaccinated fish $24 \mathrm{~d}$ after exposure were significantly lower compared to trout exposed to adjuvants alone and even 
unvaccinated fish. This may be explained by the fact that plasma antibodies in immunized and protected fish bind to invading pathogens following bacterial challenge which will result in a lowered amount of free specific antibodies in plasma (Deshmukh et al., 2013; Villumsen et al., 2012). It is believed that antibodies are involved in protection of salmonids against bacterial pathogens (Romstad et al., 2013) but in addition, it is likely that additional adaptive immune parameters are involved in protection (Deshmukh et al., 2013). Recent studies have indicated that protective responses in rainbow trout vaccinated against ERM are involving intricate immune processes and not only humoral innate factors such as lysozyme and adaptive factors such as antibodies. Thus, a wide spectrum of cells and molecules involved in innate and adaptive reactions may be decisive factors in protection of rainbow trout against $Y$. ruckeri challenge (Deshmukh et al., 2013; Chettri et al., 2015; Jaafar et al., 2015). Multifactorial immune reactions in rainbow trout were also documented in the present study but any skewing of the pattern towards a Th1 or Th2 reaction could not be established, which is in line with other vaccination responses in salmonids (Chettri et al., 2013; Kumari et al., 2013; Jaafar et al., 2015). A wide array of genes encoding cytokines involved in inflammation, innate and adaptive reactions were significantly upregulated in gills shortly after vaccination. Thus, genes encoding basic innate effector elements comprising SAA and lysozyme were upregulated early after exposure. Specific humoral elements comprising IgM, IgD and IgT genes were clearly upregulated and to different degrees in skin and gills. This is particularly interesting when addressing mucosal immunity. IgT is known to bind pathogens (bacteria and parasites) invading rainbow trout mucosal surfaces (Jørgensen et al., 2011; Xu et al., 2016) and the present findings support that $\operatorname{IgT}$ and secreted $\operatorname{IgD}$ are involved in immune reactions shortly after vaccination. T-cell dependent immunity in protection against ERM is indicated by the upregulation of CD8 $\alpha$ and TCR- $\beta$ genes in gills of fish vaccinated with bacterin-adjuvant combinations. T-cell dependent immune reactions in fish gills comply with the presence of T-cell 
rich intra-epithelial lymphoid accumulations in gills (Hordvik, 2010; Olsen et al., 2011). The mode of action of adjuvants, as applied in the present study, has not been characterized previously. We found that adjuvants used alone upregulated $\operatorname{IgD}$ genes in gills. Likewise, genes encoding proinflammatory cytokines including IL- $1 \beta$ and TNF- $\alpha$ were also clearly activated and involvement of the inflammatory pathway Th17 was indicated. In addition, upregulation of the IL-8 gene in gills followed adjuvant exposure. This chemokine attracts neutrophilic granulocytes and may play a significant role in fish responding to invasion by microorganisms. It was evident that gills reacted stronger than skin when comparing immune reactions in skin and gills of trout. When overall expression of all immune genes was analyzed comparatively it was seen that genes were expressed manifold higher (up to 23 fold) in gills compared to skin. Only two of 19 genes, the ones encoding SAA and IL-17C1, were expressed at a higher level in skin. Rainbow trout skin is anatomically composed of several dense epidermal cell layers acting as a relatively effective barrier inhibiting pathogen invasion to a higher degree than the delicate epithelial cell layer on gill lamella. This suggests that rainbow trout skin erects a high SAA production as a constitutive shield against invaders and that at least one branch of the IL-17 pathway supplements this mechanical barrier. Thus, the gene encoding IL-17C1 is generally expressed at a higher level in skin although it is not regulated. In contrast, the vulnerable gills may rely on a high constitutive production of a wider range of protective immune factors and dynamic regulation of immune genes. Especially genes encoding immunoglobulins (IgM, IgT, IgD) were more dynamically expressed in gills and at $1 \mathrm{~d}$ p.v. the isoforms IL-17C1 and IL-17C2 genes were upregulated in gills contrasting lack of regulation in skin. Yersinia ruckeri bacteria are primarily taken up by skin surfaces, whereas gills have been found to reject both live and killed bacteria (Khimmakthong et al., 2012), which could reflect the immune gene expression differences between skin and gills observed in the present study. 
In conclusion, the present study has demonstrated a significant effect of a commercial, water soluble adjuvant (Montanide ${ }^{\mathrm{TM}}$ IMS 1312 VG PR) on a series of immune parameters in rainbow trout. Merely a slight but non-significantly enhanced survival following challenge was seen but a wide array of immune genes were upregulated, particularly in gills, following immersion exposure, and lysozyme and antibody production was significantly elevated in plasma after challenge of treated fish with live bacteria. Also, $\beta$-glucan applied for immersion induced upregulation of immune genes and increased lysozyme production but no indications for increased survival was recorded. Expression of immune genes in gills were generally higher compared to that of genes in skin suggesting different mucosal response types in these two compartments. The mechanisms involved in adjuvant effects are, based on the presented results, suggested to involve a range of both innate and adaptive responses. 


\section{Acknowledgements}

This study was supported by the European Commission under FP7 (TargetFish; grant no. 311993) and the Danish Council for Strategic Research (IMPCON; grant no. 3050-00008B). The authors wish to thank aquaculture assistants John Haakonson and Claus Jespersen at the Bornholm Salmon Hatchery for rearing the experimental fish. 


\section{References}

Amend, D.F., 1981. Potency testing of fish vaccines. Dev. Biol. Stand. 49, 447-454.

Brudeseth, B.E., Wiulsrød, R., Fredriksen, B.N., Linbo, K., Løkling, K.-E., Bordevik, M., Steine, N., Klevan, A., Gravningen, K., 2013. Status and future perspectives of vaccines for industrialised fin-fish farming. Fish Shellfish Immunol. 35, 1759-1768.

Chettri, J.K., Deshmukh, R.M., Holten-Andersen, L., S., Jaafar, Dalsgaard, I., Buchmann, K., 2013. Comparative evaluation of administration methods for a vaccine protecting rainbow trout against Yersinia ruckeri $\mathrm{O} 1$ biotype 2 infections. Vet. Immunol. Immunopathol. 154, 42-47.

Chettri, J.K., Jaafar, R.M., Skov, J., Kania, P.W., Dalsgaard, I., Buchmann, K., 2015. Booster immersion vaccination using diluted Yersinia ruckeri bacterin confers protection against ERM in rainbow trout. Aquaculture 440, 1-5.

Cossarini-Dunier, M., 1986. Protection against enteric redmouth disease in rainbow trout, Salmo gairdneri Richardson, after vaccination with Yersinia ruckeri bacterin. J. Fish Dis. 9, 27-33.

Dalmo, R., Bøgwald, J., Tafalla, C., 2016. Adjuvants and delivery methods: Current and novel, in: Adams, A. (ed.), Fish Vaccines. Springer, Basel, pp. 75-105.

Dalsgaard, I., Madsen, L., 2000. Bacterial pathogens in rainbow trout, Oncorhynchus mykiss (Walbaum), reared at Danish freshwater farms J. Fish Dis. 23, 199-209.

Deshmukh, S., Kania, P.W., Chettri, J.K., Skov, J., Bojesen, A.M., Dalsgaard, I., Buchmann, K., 2013. Insight from molecular, pathological, and immunohistochemical studies on cellular and humoral mechanisms responsible for vaccine-induced protection of rainbow trout against Yersinia ruckeri. Clin. Vaccine Immunol. 20, 1623-1641.

Ellis, A.E., 1990. Lysozyme assays, in: Stolen, J.S., Fletcher, T.C., Anderson, D.P., Roberson, B.S., van Muiswinkel, W.B. (Eds.), Techniques in Fish Immunology. SOS Publications, Fair Haven, pp. 101-103. 
Gudding, R., van Muiswinkel, W.B., 2013. A history of fish vaccination: Science-based disease prevention in aquaculture. Fish Shellfish Immunol. 35, 1683-1688.

Hordvik, I., 2010. Salmonid T cells assemble in the thymus, spleen and in the novel interbranchial lymphoid tissue. J. Anat. 217, 728-739.

Jaafar, R.M., Chettri, J.K., Dalsgaard, I., Al-Jubury, A., Kania, P.W., Skov, J., Buchmann, K., 2015. Effects of adjuvant Montanide ${ }^{\mathrm{TM}}$ ISA 763 A VG in rainbow trout injection vaccinated against Yersinia ruckeri. Fish Shellfish Immunol. 47, 797-806.

Jaafar, R.M., Al-Jubury, A., Chettri, J.K., Dalsgaard, I., Kania, P.W., Buchmann, K., 2017. Secondary immune response of rainbow trout following repeated immersion vaccination. J. Fish Dis. In press.

Jeney, G., Anderson, D.P., 1993. Glucan injection or bath exposure given alone or in combination with a bacterin enhance the non-specific defence mechanisms in rainbow trout (Oncorhynchus mykiss). Aquaculture 116, 315-329.

Johnson, K.A., Flynn, J.K., Amend, D.F., 1982. Duration of immunity in salmonids vaccinated by direct immersion with Yersinia ruckeri and Vibrio anguillarum bacterins. J. Fish Dis. 5, 207-213. Johnson, K.A., D.F. Amend, 1983. Comparison of efficacy of several delivery methods using Yersinia ruckeri bacterin on rainbow trout, Salmo gairdneri Richardson. J. Fish Dis. 6, 331-336. Jørgensen, L.v.G., Heinecke, R.D., Skjødt, K., Rasmussen, K.J., Buchmann, K., 2011. Experimental evidence for direct in situ binding of IgM and IgT to early trophonts of Ichthyophthirius multifiliis (Fouquet) in the gills of rainbow trout, Oncorhynchus mykiss (Walbaum). J. Fish Dis. 34, 749-755.

Khimmakthong, U., Deshmukh, S., Chettri, J.K., Bojesen, A.M., Kania, P.W., Dalsgaard, I., Buchmann, K., 2013. Tissue specific uptake of inactivated and live Yersinia ruckeri in rainbow trout (Oncorhynchus mykiss): Visualization by immunohistochemistry and in situ hybridization. Microb. Pathog. 59-60, 33-41. 
Kumari, J., Bøgwald, J., Dalmo, R.A., 2013.Vaccination of Atlantic salmon, Salmo salar L., with Aeromonas salmonicida and infectious pancreatic necrosis virus (IPNV) showed a mixed Th1/Th2/Treg response. J. Fish Dis. 36, 881-886.

Livak, K.J., Schmittgen, T.D., 2001. Analysis of relative gene expression data using real-time quantitative PCR and the $2^{-\Delta \Delta C T}$ method. Methods 25, 402-408.

Newman, S.G., Majnarich, J.J., 1982. Direct immersion vaccination of juvenile rainbow trout, Salmo gairdneri Richardson, and juvenile coho salmon, Oncorhynchus kisutch (Walbaum), with a Yersinia ruckeri bacterin. J. Fish Dis. 5, 339-341.

Olsen, M.M., Kania, P.W., Heinecke, R.D., Skjoedt, K., Rasmussen, K.J., Buchmann, K., 2011. Cellular and humoral factors involved in the response of rainbow trout gills to Ichthyophthirius multifiliis infections: Molecular and immunohistochemical studies. Fish Shellfish Immunol. 30, 859-869.

Przybylska-Diaz, D.A., Schmidt, J.G., Vera-Jiménez, N.I., Steinhagen, D., Nielsen, M.E., 2013. $\beta$ glucan enriched bath directly stimulates the wound healing process in common carp (Cyprinus carpio L.). Fish Shellfish Immunol. 35, 998-1006.

Romstad, A.B., Reitan, L.J., Midtlyng, P., Gravningen, K., Evensen, Ø., 2012. Antibody responses correlate with antigen dose and in vivo protection for oil-adjuvanted experimental furunculosis (Aeromonas salmonicida subsp. salmonicida) vaccines in Atlantic salmon (Salmo salar L.) and can be used for batch potency testing of vaccines. Vaccine 31, 791-796.

Rørstad, A., Aasfjord, P., Robertsen, B., 1993. Adjuvant effect of a yeast glucan in vaccines against furunculosis in Atlantic salmon (Salmo salar L.). Fish Shellfish Immunol. 3, 179-190.

Schmidt, J.G., Henriksen, N.H., Buchmann, K., 2016. ERM booster vaccination of rainbow trout using diluted bacterin: Field studies. Aquaculture 464, 262-267. 
Schmittgen, T., Livak, K.J., 2008. Analyzing real-time PCR data by the comparative $C_{\mathrm{T}}$ method. Nat. Protoc. 3, 1101-1108.

Selvaraj, V., Sampath, K., Sekar, V., 2006. Adjuvant and immunostimulatory effects of of $\beta$-glucan administration in combination with lipopolysaccharide enhances survival and some immune parameters in carp challenged with Aeromonas hydrophila. Vet. Immunol. Immunopathol. 114, 1524.

Skov, J., Kania, P.W., Holten-Andersen, L., Fouz, B., Buchmann, K., 2012. Immunomodulatory effects of dietary $\beta$-1,3-glucan from Euglena gracilis in rainbow trout (Oncorhynchus mykiss) immersion vaccinated against Yersinia ruckeri. Fish Shellfish Immunol. 3, 111-120.

Soltani, M., Shafiei, Sh., Yosefi, P., Mosavi, Sh., Mokhtari, A., 2014. Effect of Montanide ${ }^{\text {TM }}$ IMS 1312 VG adjuvant on efficacy of Yersinia ruckeri vaccine in rainbow trout (Oncorhynchus mykiss). Fish Shellfish Immunol. 37, 60-65.

Soltani, M., Mokhtari, A., Mirzargar, S.S., Taherimirghaed, A., Zargar, A., Shafiei, Sh., HosseiniShekarabi, S.P., 2016. Efficacy and immune response of intraperitoneal vaccination of rainbow trout (Oncorhynchus mykiss) with a Yersinia ruckeri bacterin formulated with Montanide ${ }^{\mathrm{TM}}$ ISA 763 AVG adjuvant. Bull. Eur. Ass. Fish Pathol. 36, 225-236.

Tafalla, C., Bøgvald, J., Dalmo, R.A., 2013. Adjuvants and immunostimulants in fish vaccines: Current knowledge and future perspectives. Fish Shellfish Immunol. 35, 1740-1750.

Tobback, E., Decostere, A., Hermans, K., Haesebrouck, F., Chiers, K., 2007. Yersinia ruckeri infections in salmonid fish. J. Fish Dis. 30, 257-268.

Villumsen, K.R., Dalsgaard, I., Holten-Andersen, L., Raida, M.K., 2012. Potential role of specific antibodies as important vaccine induced protective mechanism against Aeromonas salmonicida in rainbow trout. PlosOne 7, e46733. 
Wheeler, R.W., Davies, R.L., Dalsgaard, I., Garcia, J., Welch, T.J., Wagley, S., Bateman, K.S., Verner-Jeffreys, D.W., 2009. Yersinia ruckeri biotype 2 isolates from mainland Europe and the UK likely represent different clonal groups. Dis. Aquat. Organ. 84, 25-33.

Xu, Z., Takizawa, F., Parra, D., Gómez, D., Jørgensen, L.v.G., LaPatra, S.E., Sunyer, J.O., 2016. Mucosal immunoglobulins at respiratory surfaces mark an ancient association that predates the emergence of tetrapods. Nat. Commun. 7, 10728.

Xueqin, J., Kania, P.W., Buchmann, K. 2012. Comparative effects of four feed types on white spot disease susceptibility and skin immune parameters in rainbow trout, Oncorhynchus mykiss (Walbaum). J. Fish Dis. 35, 127-135.

Zhang, Z., Swain, T., Bøgwald, J., Dalmo, R.A., Kumari, J., 2009. Bath immunostimulation of rainbow trout (Oncorhynchus mykiss) fry induces enhancement of inflammatory cytokine transcripts, while repeated bath induce no changes. Fish Shellfish Immunol. 26, 677-684. 
Fig. 1. Survival (\%) of rainbow trout following the primary Y. ruckeri bath challenge. At day 12 post primary challenge, all survivors were exposed to a secondary $Y$. ruckeri bath challenge (see 2.5).

Fig. 2. A. Lysozyme activity levels in plasma. Each bar represents the mean $\pm \operatorname{SEM}(n=10)$. Significant difference between experimental groups were only observed post challenge $(P<0.05-$ $P<0.001$ ) (see 3.2). Bars sharing the same letter are not significantly different. B. Antibody (IgM) levels in plasma against $Y$. ruckeri. Each bar represents the mean $\pm \operatorname{SEM}(n=10)$. A star indicates significant difference from unvaccinated, uninfected fish $(P<0.0001)$ (see 3.3).

Fig. 3. Overall gene expression level in skin (A) and gills (B) of rainbow trout based on all experimental groups and all sampling time-points. The overall gene expression level in gills relative to skin $(\mathrm{C})$ is shown as the ratio Gene expression in gills/Gene expression in skin for each gene. Figures above spot columns of A and B represent the total number of fish expressing a particular gene (having a $\mathrm{Cq}$ value) (some fish samples did not show gene expression at all).

Fig. 4. Gene expression profiles in gill tissue of rainbow trout (A-R). Each bar represents the mean \pm SEM $(n=10)$. A star indicates significant difference from unvaccinated, uninfected controls $(P<$ $0.05)$. Significant difference $(P<0.05)$ between the vaccine-MA and vaccine-YWG combinations and the vaccine alone is indicated by $\mathrm{M}$ or $\mathrm{Y}$, respectively. Hatched columns indicate vaccinated fish.

Fig. 5. Gene expression profiles in skin tissue of rainbow trout (A-O). Each bar represents the mean \pm SEM $(n=10)$. A star indicates significant difference from unvaccinated, uninfected controls $(P<$ $0.05)$. Significant difference $(P<0.05)$ between the vaccine-MA and vaccine-YWG combinations and the vaccine alone is indicated by $\mathrm{M}$ or $\mathrm{Y}$, respectively. Hatched columns indicate vaccinated fish.

Supplementary table S1. A complete overview of gene expression data obtained, i.e. $P$ values, fold regulation, SEM, and proportion (\%) of Cq values, obtained for each gene at each sampling timepoint, provided as an Excel file containing a separate sheet for gill tissue and a separate sheet for skin tissue. 


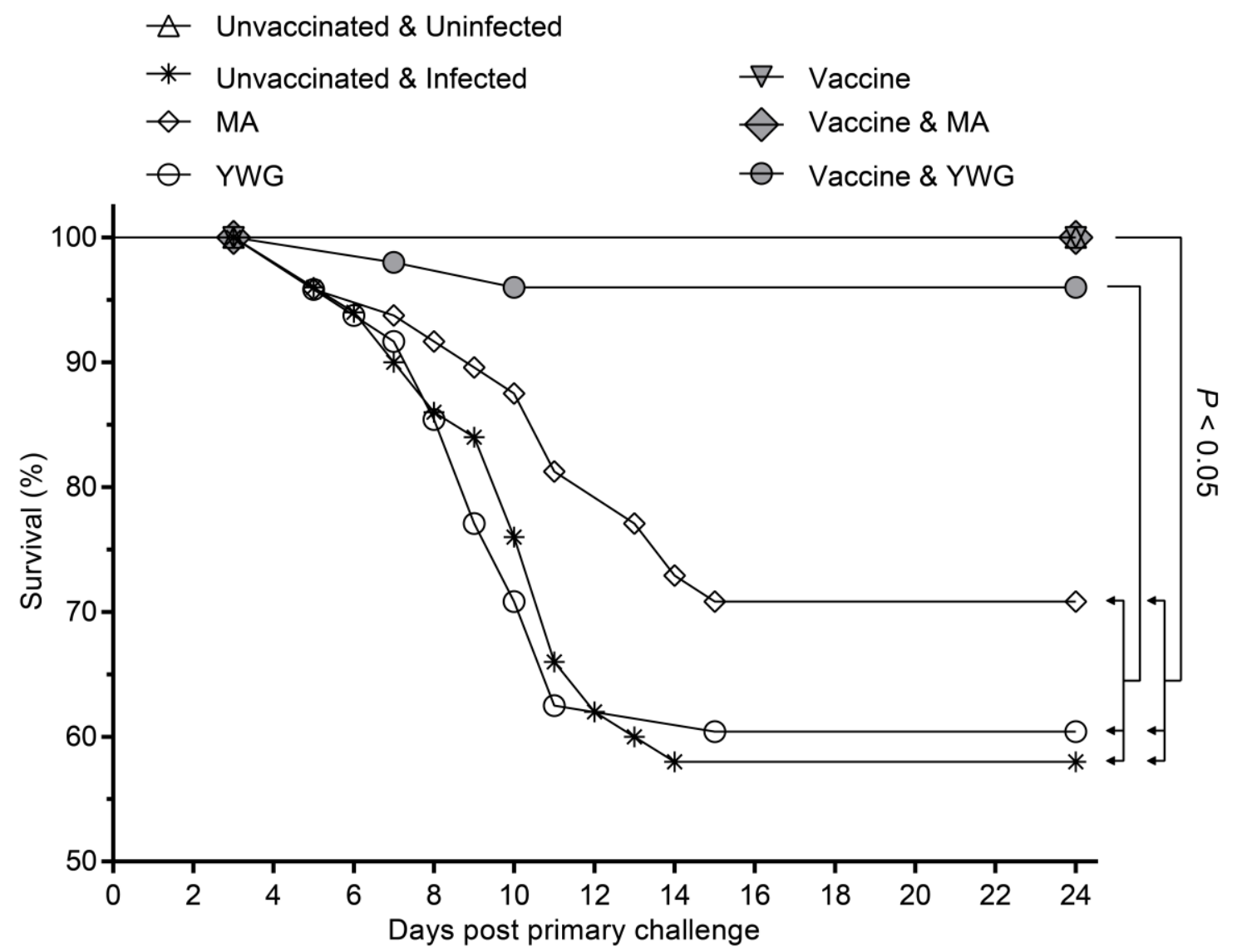

Fig.1 
$\square$ Unvaccinated \& Uninfected

$\begin{array}{ll}\text { Unvaccinated \& Infected } & \square \text { Vaccine } \\ \text { MA } & \text { Vaccine \& MA } \\ \text { YWG } & \text { Vaccine \& YWG }\end{array}$

A: Lysozyme activity in plasma
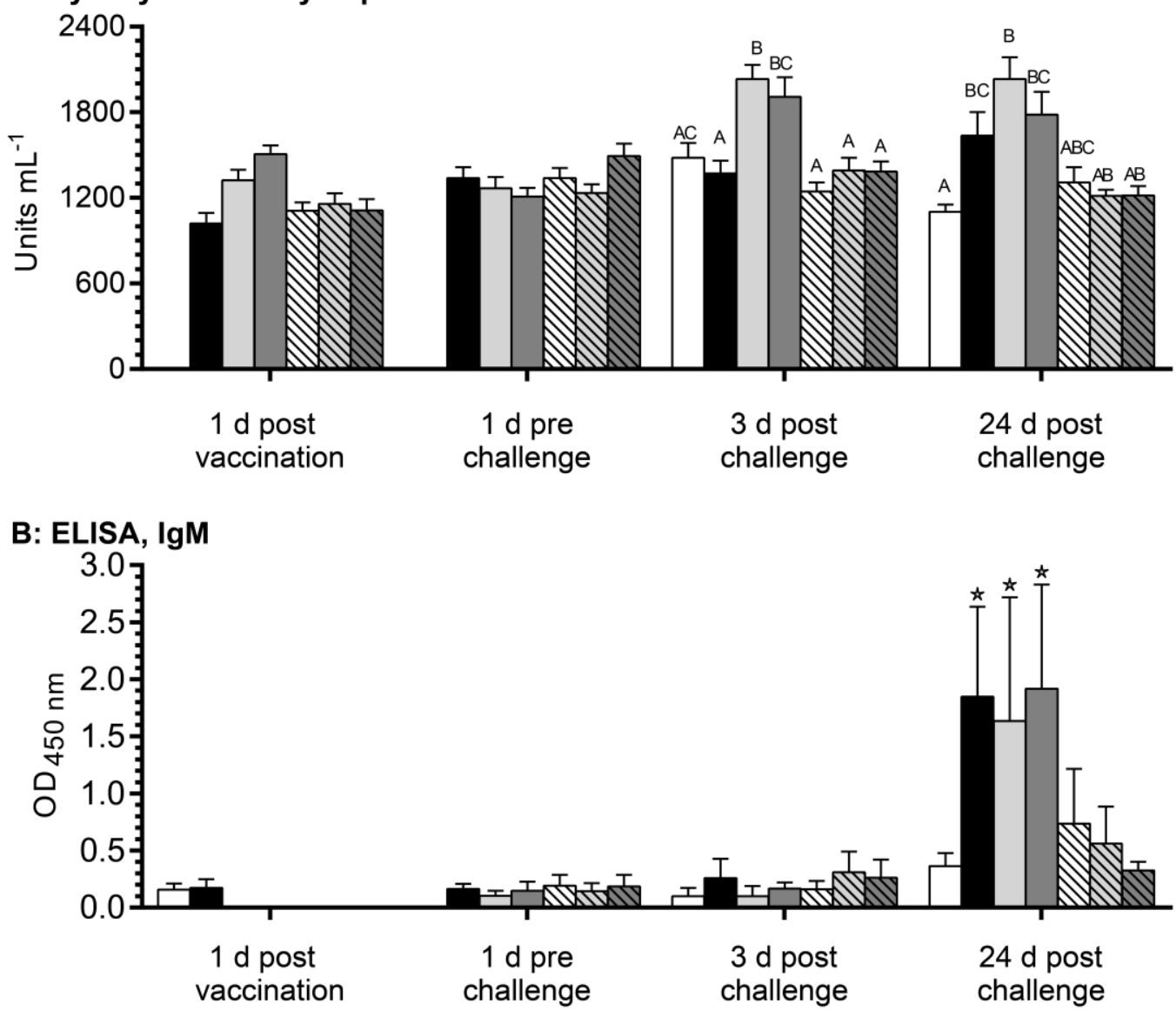

Fig.2 

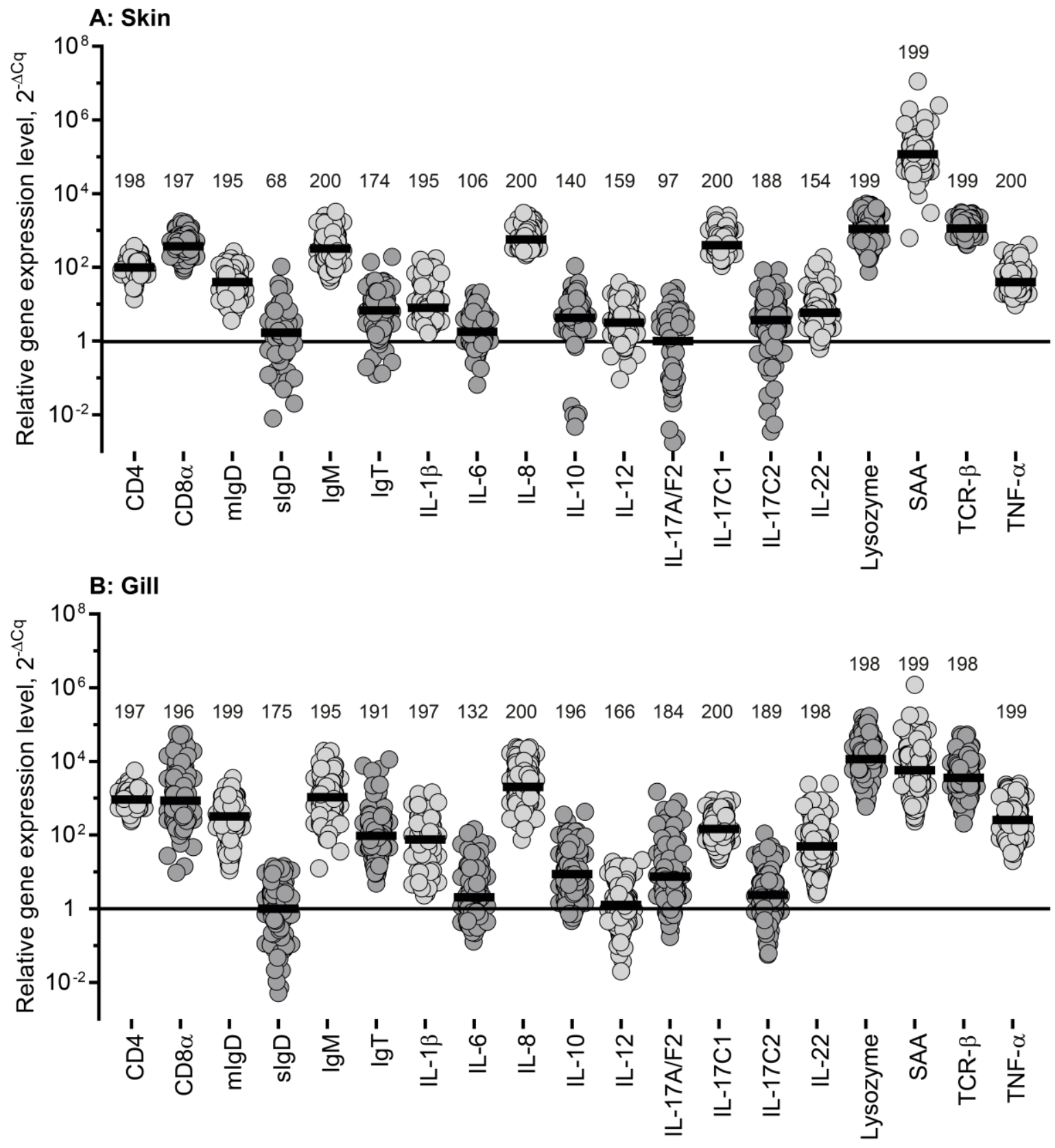

\section{C: Gene expression level of gill relative to skin}

$$
\begin{aligned}
& \begin{array}{lllllllllllllllllll}
22.8 & 5.6 & 19.6 & 1.4 & 9.6 & 19.6 & 23.0 & 2.9 & 8.7 & 5.0 & 1.0 & 18.0 & -1.1 & 1.5 & 20.3 & 25.2 & -8.5 & 7.8 & 15.6
\end{array}
\end{aligned}
$$

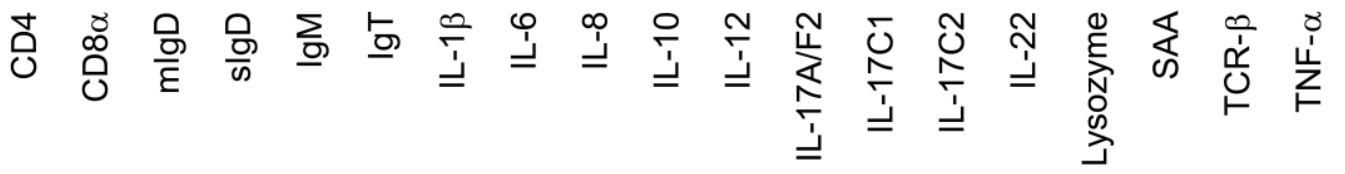

Fig.3 


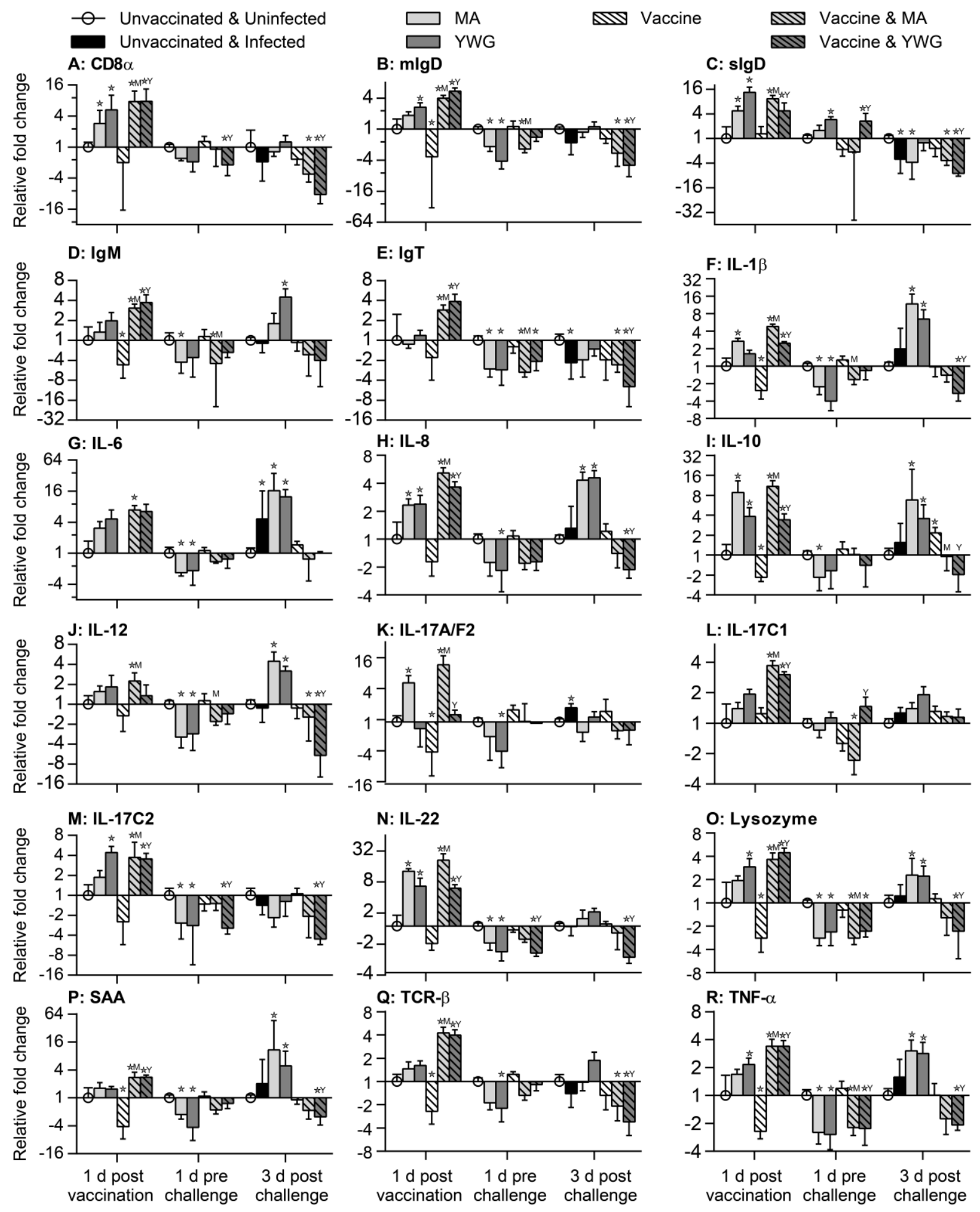

Fig.4 

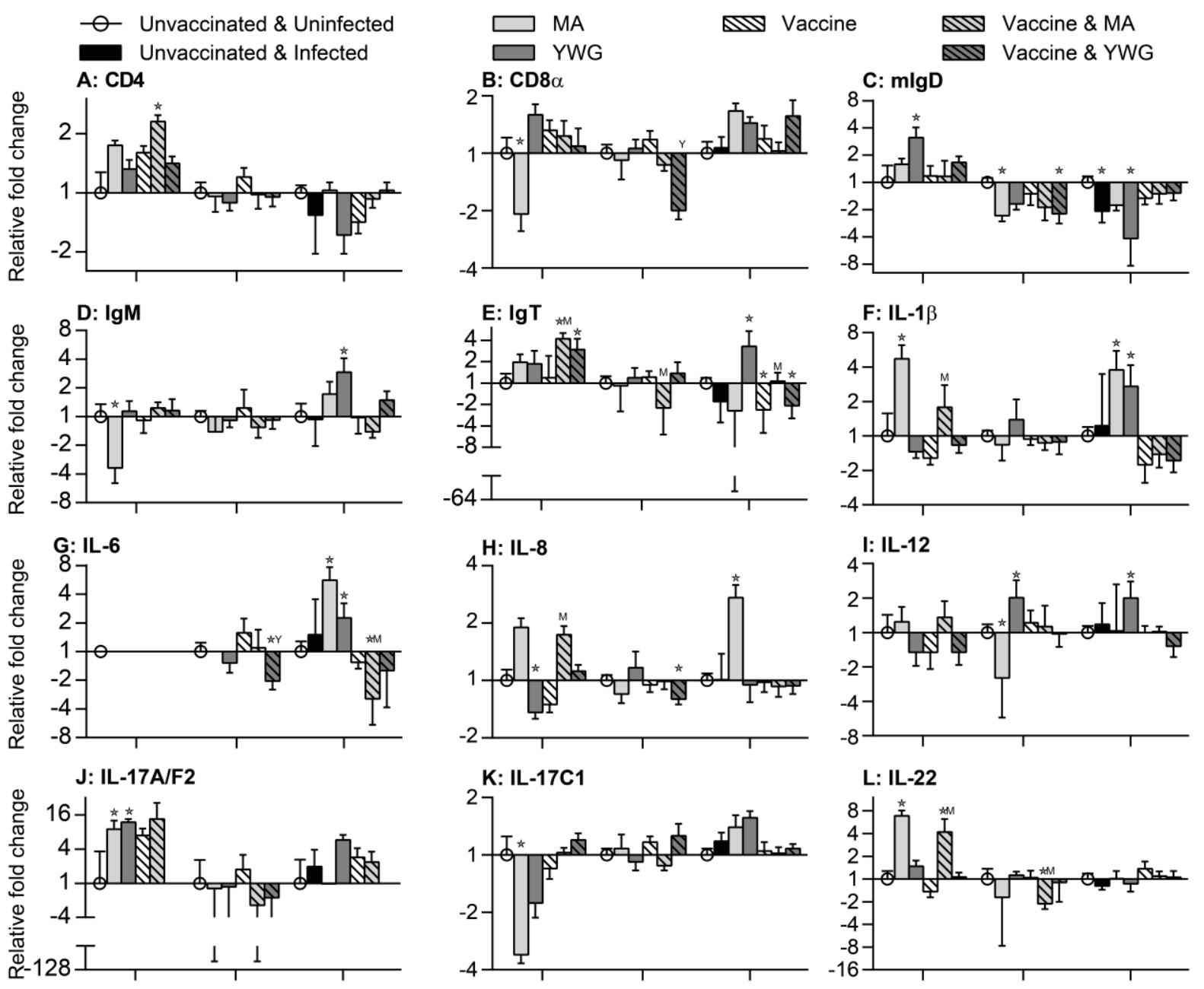

L: IL-22
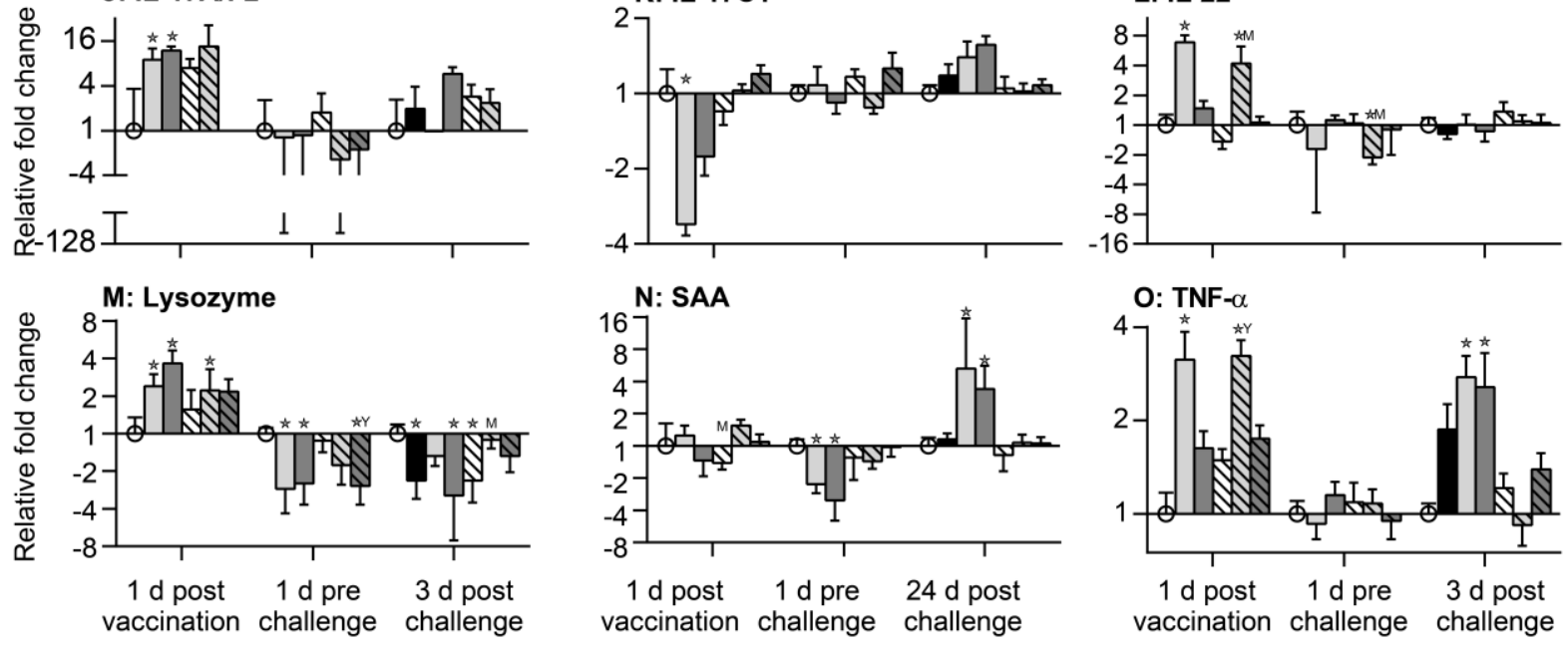

Fig. 5 
Table 1. Genes analyzed (listed in alphabetical order) incl. primer and probe ( $\left.5^{\prime}-3^{\prime}\right)$ sequences applied in qPCR assays.

\begin{tabular}{|l|l|l|l|l|}
\hline Gene & GenBank acc. no. & Forward primer & Reverse primer & Probe \\
\hline CD4 & AY973028 & cattagcctgggtggtcaat & ccctttcttgacagggaga & cagaagagagagctggatgtctccg \\
\hline CD8 $\alpha$ & AF178054 & acaccaatgaccacaaccatagag & gggtccacctttcccacttt & accagctctacaactgccaagtcgtgc \\
\hline EF-1 ${ }^{*}$ & AF498320 & accetcctcttggtcgtttc & tgatgacaccaacagcaaca & gctgtgcgtgacatgaggca \\
\hline mIgD & AY870262 & caggaggaaagttcggcatca & cctcaaggagctctggtttgga & ccacaccacacagactctggccctgaa \\
\hline sIgD & JQ003979 & tggcacgccaggatttgac & tcagaattgagtgaacggacagaca & ccacaccacacagactctggccctgaa \\
\hline IgM $* *$ & S63348 & cttggcttgttgacgatgag & ggctagtggtgttgaattgg & tggagagaacgagcagttcagca \\
\hline IgT $* *$ & agcaccagggtgaaacca & gcggtgggttcagagtca & agcaagacgacctccaaaacagaac \\
\hline IL-1 $\beta$ & AJ870265 23954 & acattgccaacctcatcatcg & ttgagcaggtccttgtccttg & catggagaggttaaagggtggc \\
\hline IL-6 & DQ866150 & actcccctctgtcacacacc & ggcagacaggtcctccacta & ccactgtgctgatagggctgg \\
\hline IL-8 & AJ279069 & agaatgtcagccagccttgt & tctcagactcatcccctcagt & ttgtgctcctggccctcctga \\
\hline IL-10 & AB118099 & cgactttaaatctcccatcgac & gcattggacgatctctttttc & catcggaaacatcttccacgagct \\
\hline IL-12 & HE798148 & caacggaacaccacattcag & agcctgtagtgaggcagcat & tgcgtgtctgaggaacatccg \\
\hline IL-17A/F2 & AJ580842 & tcaaaagcaacgtgtcgaag & tccctctgattcctctgtgg & tatgctgctgggcctgacca \\
\hline IL-17C1 & CAW30792 & ctggcggtacagcatcgata & gagttatatccataatcttcgtattcggc & cgtgatgtccgtgccctttgacgatg \\
\hline IL-17C2 & CAW30793 & ctggcggtacagcatcgata & cagagttatatgcatgatgttgggc & cgtggtgtccaggccctttaatgatg \\
\hline IL-22 & AM748537 2 & attcctttccctcctccat & ctttccgcaagaagttgtccgag \\
\hline Lysozyme & X59491 & atgaccaccaccacagcatt & gtcaacaccacacgctt & atacccaggccaccaaccgcaacac \\
\hline SAA & AM422446 & gaaacagcctgcccaact & ttacgtccccagtggttagc & tcgaggacacgaggactcagca \\
\hline TCR- $\beta$ & AF329700 & gggagatgattcagggttcca & aagctgacaatgcaggtgaatc & ccaatgaatggcacaaaccagagaa \\
\hline TNF- $\alpha(1$ and 2) & AJ277604 and AJ401377 & ggggacaaactgtggactga & gaagttcttgccctgctctg & gaccaatcgactgaccgacgtgga \\
\hline
\end{tabular}

* Reference gene

** Primers for IgM and IgT amplified both secreted and membrane bound forms. 
Highlights

- Immune-related genes were upregulated following exposure to both adjuvants, i.e. either Montanide ${ }^{\mathrm{TM}}$ or $\beta$-glucan

- Both vaccine-adjuvant combinations induced different immune gene regulation when compared the vaccine exposed fish alone

- Immune-related genes were expressed at a higher level in gills compared to skin

- A trend towards increased survival following Y. ruckeri bath challenge was seen in Montanide ${ }^{\mathrm{TM}}$-treated trout

- No effect on survival was seen in $\beta$-glucan-treated trout 